\title{
ANALISIS TRANSLATION SHIFT DALAM PENERJEMAHAN BILINGUAL BAHASA INGGRIS - BAHASA INDONESIA
}

\author{
Yosa Abduh Alzuhdy
}

\begin{abstract}
ABSTRAK
Meskipun dianggap merupakan konsep yang klasik, teori pergeseran terjemahan (translation shift) yang diperkenalkan oleh J.C. Catford lewat buku yang merupakan kumpulan materi kuliahnyaA Linguistic Theory of Translation(1965) masih sangat sering dipakai dalam analisis penelitian terjemahan. Namun, dalam beberapa referensi yang membahas pergeseran terjemahan ini terdapat beberapa perbedaan maupun keterbatasan dalam hal penerapan analisisnya, sehingga dapat menimbulkan masalah bagi peneliti yang ingin menerapkan teori ini dalam penelitian mereka. Pergeseran terjemahan itu dibagi menjadi dua jenis, yaitu level shift dan category shift, yang dimaksudkan untuk mencapai tingkat kesepadanan (equivalence) yang baik bagi kualitas terjemahan yang dihasilkan, baik karena tidak terdapatnya korespondensi formal (formal correspondence) maupun yang disebabkan oleh alasan-alasan lain, misalnya karena gaya penulisan, pemilihan kata, atau keinginan penerjemah. Category shift selanjutnya dibagi lagi menjadi empat sub bagian, yaitu structure shift, class shift, unit shift dan intra-system shift. Dalam artikel ini penulis mencoba meninjau kembali teori pergeseran terjemahan (translation shift) klasik yang diperkenalkan Catford dengan mengaplikasikannya pada contoh-contoh penerjemahan dari bahasa Inggris ke bahasa Indonesia atau sebaliknya.
\end{abstract}

Kata kunci: Catford, translation shift, kesepadanan,

\section{A SHIFT TRANSLATION ANALYSIS OF THE ENGLISH - INDONESIA BILINGUAL}

\begin{abstract}
Although considered a classic concept, the translation shift theoryintroduced by J.C. Catford through his book - which was a collection of lectures - A Linguistic Theory of Translation (1965) is still frequently used in analyzing translation research. However, some references discussing this translation shifts contain some differences, inaccuracies, or at least limitations in applying the analysis. Therefore, it may result in some problems for the researchers to apply this theory in their studies. Catford distinguishes the translation shifts into two types, i.e. level shift and category shift, which aim to achieve good equivalence for the quality of resulted translations. These shifts may result from the lack of formal correspondence or other reasons, such as the style of writing, diction, or the translator's willingness. The second type, category shifts, is further differentiated into four parts, i.e. structure shift, class shift, unit shift and intra-system shift. In this article, the writer tries to review the classic theory of translation shiftsintroduced by Catford by applying them in the samples taken from English into Bahasa Indonesia translations and vice versa.
\end{abstract}

Keywords: Catford, translation shift, equivalence

\section{A. PENDAhuluan}

Dalam era global yang semakin memperpendek rentangan ruang dan waktu dalam kegiatan manusia, komunikasi menjadi satu hal yang sangat vital. Segala macam aktivitas yang dilakukan tentu memerlukan adanya komunikasi yang baik agar dapat dipahami oleh pihak-pihak yang terlibat, sehingga tujuan yang ingin dicapai dalam aktivitas itu lebih mungkin teraih. Dengan semakin pesatnya perkembangan pengetahuan, teknologi, ekonomi, budaya, pariwisata, dan sebagainya, kebutuhan akan akses ke sumber informasi yang tersedia pun terasa semakin tinggi dan mendesak. 
Globaliasi menyatukan atau setidaknya menghubungkan beragam komunitas dari berbagai latar belakang bangsa, budaya, bahasa, agama, dan sebagainya. Komunikasi yang diperlukan pun seringkali harus dilakukan lintas bahasa, sehingga bagi sebagian orang, ini menjadi kendala karena keterbatasannya memahami tindak komunikasi yang dilakukan dalam bahasa yang berbeda. Di sini, terjemahan menjadi salah satu jembatan untuk mencapai pemahaman komunikasi lintas bahasa tersebut.

Perkembangan kegiatan penerjemahan yang sangat pesat melahirkan kajian terjemahan (Translation Studies) yang juga sangat cepat berkembang. Berbagai teori dan model diajukan oleh para ilmuwan. Dari sekian banyak teori yang diajukan, salah satu yang dianggap klasik adalah apa yang diperkenalkan oleh J.C. Catford A Linguistic Theory of Translation. Meskipun sudah lebih dari setengah abad, namun dalam berbagai analisis terjemahan yang dilakukan, teori Catford masih sering digunakan, terutama yang terkaitan dengan pergeseran terjemahan (translation shift).

Meskipun banyak dikritik oleh ilmuwan penerjemahan modern terutama dalam kaitannya dengan kajian translasi kontemporer, teori yang diperkenalkan oleh Catford masih tetap bertahan dan dipergunakan hingga saat ini, karena memang translationshift tidak bisa dihindari dalam setiap kegiatan penerjemahan (Al-Zoubi, 2003). Kritik itu terutama diarahkan pada defenisi terjemahan yang menurut Catford bukan merupakan pengalihan makna, melainkan penggantian teks dari satu bahasa ke bahasa lainnya. Sebagai seorang bahasawan dan ahli ilmu fonetik, ia mendasarkan teorinya pada linguistik perbandingan, dengan selalu mengaitkan penerjemahan itu pada pendekatan kebahasaan (Machali, 2000: 5).

Fenomena penerjemahan yang begitu besar juga menarik banyak orang untuk melakukan kajian terkait dengan kegiatan translasi ini, baik dari sisi proses, produk, maupun pelatihannya. Sayangnya, dari sekian banyak penelitian yang dilakukan itu, masih terbatas yang mengarah pada konsep translation shift, sehingga pemahaman tentang shift ini sering juga kurang memadai. Dalam beberapa penulisan skripsi ma- hasiswa yang fokus kajiannya terkait translation shift, sering dijumpai kelemahan dan bahkan kekeliruan pemahaman yang berakibat pada kelemahan dalam analisis yang dilakukan.

\section{B. TRANSLATION SHIF}

Catford (1965:73) menyatakan bahwa "shifts in translation" atau pergeseran dalam terjemahan artinya berpindah atau bergeser dari korespondensi formal (formal correspondence) dalam proses pemindahan teks dari bahasa sumber (Bsu) ke bahasa sasaran (Bsa) agar hasil terjemahannya berterima, sedangkan Newmark (1988: 26 \& 85) menggunakan istilah "transposisi" untuk mencapai level "naturalness" tertentu dalam upaya untuk menghasilkan terjemahan yang dapat berterima itu.

Kata "formal" dalam "korespondensi formal" berasal dari kata "form" (bentuk), jadi maksudnya adalah "bentuk linguistik"; sehingga dapat juga diterjemahkan menjadi kesamaan bentuk linguistik (Hariyanto, 2009). Catford menyatakan bahwa korespondensi formal merujuk pada kesamaan kategori linguistik dari dalam dua bahasa yang berbeda (unit, kelas, struktur, elemen struktur, dll.), bisa saling bertukar tempat pada "posisi yang sama" (Cartford, 1965: 27).Bisa jadi, meskipun sangat jarang terjadi, terjemahan itu setara sampai pada tingkatan kata atau bahkan morfem. Misalnya:

Teks sumber (Tsu): Budi akan pergi ke sekolah besok.

Teks sasaran (Tsa): Budi will go to school tomorrow.

Setiap kata dalam bahasa sumber memiliki padanan yang berkorespondensi secara formal dengan kata yang sama pada bahasa sasaran.

Namun, yang lebih sering terjadi, adalah adanya perubahan atau pergeseran dalam penerjemahan, karena tidak terdapatnya formal correspondence dalam kedua bahasa yang terlibat. Perubahan atau pergeseran inilah yang disebut translation shift. Menurut Catford, ada dua jenis shift yang mungkin terjadi, yaitu level shifts (pergeseran tingkat) dan category shifts (pergeseran kategori). 


\section{Level Shift}

Catford menyatakan bahwa level shiftterjadi ketika suatu ekspresi dalam bahasa sumber (Bsu) memiliki padanan dalam bahasa sasaran (Bsa) pada level yang berbeda. Catford menjelaskan sebelumnya (1965:3) bahwa yang dimaksud dengan level di sini adalah strukturisasi dimensi bahasa berdasarkan pada substansi fonik, substansi grafik, dan substansi situasi. Perhatikan ilustrasi berikut ini:

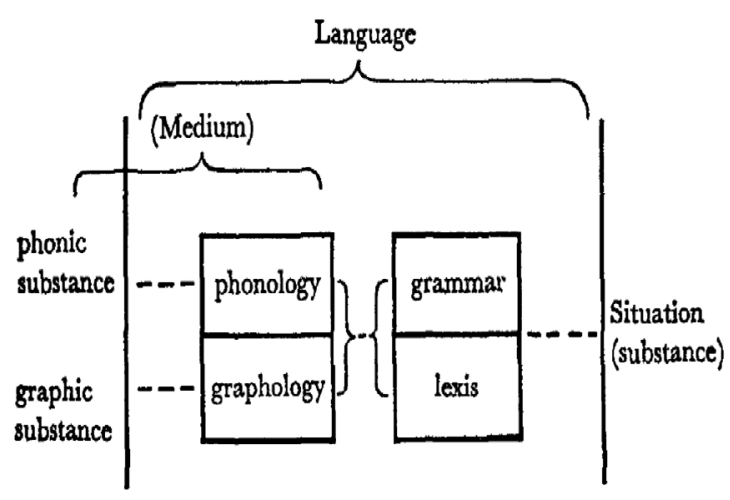

Gambar 1. Analisis tingkatan bahasa (Catford, 1965:3)

Kita dapat melihat bahwa Catford memahami bahasa dalam dua tingkatan/level yaitu leksikon dan grammar, yang dapat diekspresikan melalui dua media, yaitu lisan (fonik) dan tulisan (grafik). Lebih lanjut ia menyatakan (1965: 4):

"Grammar [is] the level of linguistic form at which operate closed system: the characteristics of a closed system being: (1) the number of terms is finite; (2) each term is exclusive of the others; (3) any change in the number of terms would change the 'values'(or 'formal meanings') of the other terms (e.g. systems of pronouns, of deictics, of number, of case, of tense... etc.), [while] lexis [is] the level of linguistic form at which operate open sents (e.g. the open sets of items often occurring as examples or 'exponents' of nouns, verbs, etc.)."

Halliday dan Matthiesen (2004: 20) dalam bukunya yang memperkenalkan functional grammar menyatakan bahwa bahasa memiliki banyak dimensi atau bentuk urutan dan prinsip pengurutannya seperti Tabel 1 .
Tabel 1. Dimensi (bentuk urutan) bahasa dan prinsip pengurutannya

\begin{tabular}{|c|c|c|c|}
\hline & dimension & principle & Orders \\
\hline 1 & $\begin{array}{l}\text { structure } \\
\text { (syntagmatic } \\
\text { order) }\end{array}$ & Rank & $\begin{array}{l}\text { clause } \sim \text { group/phrase } \\
\sim \text { word } \sim \text { morpheme }\end{array}$ \\
\hline 2 & $\begin{array}{l}\text { system } \\
\text { (paradigmatic } \\
\text { order) }\end{array}$ & delicacy & $\begin{array}{l}\text { grammar lexis } \\
\text { (lexicogrammar) }\end{array}$ \\
\hline 3 & stratification & realization & $\begin{array}{l}\text { semantics } \sim \\
\text { lexicogrammar } \sim \\
\text { phonology } \sim \text { phonetics }\end{array}$ \\
\hline 4 & instantiation & instantiation & $\begin{array}{l}\text { potential } \sim \text { sub- } \\
\text { potential or instance } \\
\text { type } \sim \text { instance }\end{array}$ \\
\hline 5 & metafunction & metafunction & $\begin{array}{l}\text { ideational } \\
{[\text { logical experimental] }} \\
\sim \text { interpersonal } \sim \\
\text { textual }\end{array}$ \\
\hline
\end{tabular}

Level shift yang dimaksudkan oleh Catford di sini adalah pergeseran yang terjadi dari tingkatan grammar ke lexis atau sebaliknya. Artinya bahwa suatu tatanan gramatik dalam suatu bahasa (misalnya pembentukan kala perfektif bahasa Inggris dengan pola have+Vb3), karena perbedaan tata bahasa, akan harus diterjemahkan menjadi tingkat kata (lexis) dalam bahasa lain (misalnya dalam Bahasa Indonesia,dengan menggunakan kata "sudah" atau "telah" (Machali, 1998:14).

Contoh

Tsu: John has stopped smoking.

Tsa: John sudah berhenti merokok.

Penanda gramatika perfektif "has stopped" dalam bahasa Inggris diterjemahkan menjadi kata (lexis) "sudah"dalam bahasa Indonesia.

Sebagai perbandingan, perhatikan Hariyanto (2009), yang memberi contoh penggunaan level shift pada kalimat berikut:

Tsu: She is walking alone.

Tsa:Dia sedang berjalan sendirian.

Selanjutnya, Hariyanto menyatakan bahwa level shift terjadi dalam kasus penerjemahan di atas karena morfem terikat "-ing" dalam bahasa Inggris diterjemahkan menjadi leksikon atau kata (morfem bebas) "sedang" dalam bahasa Indonesia.

Penjelasan tersebut sebenarnya kurang tepat. Bila difokuskan pada pergeseran penerjemahan morfem terikat "-ing” dalam bahasa Inggris menjadi leksikon atau kata (morfem 
bebas) "sedang” dalam bahasa Indonesia, maka yang terjadi bukan level shift, melainkan unit shift - Catford (1965:70) juga menyebutnya sebagai changes in rank, atau rank shift, yaitu pergeseran satuan gramatika yang lebih rendah (morfem) ke satuan yang lebih tinggi (kata), sehingga terjadi upward rank shift.Unit shift akan dibahas lebih jauh pada point 2.c.

Tumpang-tindihnya pemahaman antara unit shift dan level shift ini tampaknya cukup kerap terjadi (lihat, misalnya, Nugroho, 2013:25; Pradipta, 2013:14-15; Listiari, 2012:6; Winarna, 2009:15-17), sehingga kadang-kadang bahkan dinyatakan bahwa level shift itu sama dengan unit shift atau rank shift. Padahal keduanya berbeda. Unit/rank shift adalah adalah bagian dari category shift.

Bila kita melihat contoh yang dikemukakan Hariyanto di atas, sebenarnya memang terdapat level shift dalam penerjemahan tersebut, tetapi yang ditunjukkan mestinya pergeseran bentuk gramatikal "to be +Vb-ing" (is walking) yang dimaksukan untuk mengindikasikan present continuous tense (sesuatu yang sedang berlangsung pada saat ungkapan itu diucapkan), menjadi leksikon kata "sedang" dalam Bahasa Indonesia.

Contoh lain bisa dilihat pada pengalihan bentuk partikel "-lah" yang dalam bahasa Indonesia berfungsi menunjukkan penekanan pada kata, dan diganti menjadi bentuk tan-persona "it+tobe" dalam bahasa Inggris.

Bsu: Zulfalah yang mengembalikan buku itu ke perpustakaan.

Bsa: It was Zulfa who returned the book to the library.

Dalam kasus ini, bukan pergeseran atau perubahan morfem "-lah" menjadi klausa "it was" yang diambil, tetapi lebih pada fungsi partikel "-lah" yang dalam bahasa Indonesia sepadan dengan fungsi "it+tobe" dalam konstruk kalimat tersebut. Bila perubahan morfem "-lah" menjadi klausa "it was" yang kita fokuskan, maka, alih-alih level shift, yang terjadi adalah unit shift.

\section{Category Shift}

Category shift terjadi ketika terdapat perubahan atau pergeseran terjemahan dari korespondensi formal, dari bentuk yang setara antara bahasa sumber dan bahasa sasaran, seperti contoh yang di atas, di mana terjemahan itu setara sampai pada tingkatan kata atau bahkan morfem. Dalam hal ini tidak perlu ada pergeseran atau shift apapun, karena masing-masing kata dalam bahasa sumber dan bahasa sasaran memiliki padanan yang berkorespondensi secara formal.

Namun seperti telah dijelaskan di depan, yang lebih lazim terjadi adalah terdapat perubahan atau pergeseran bentuk untuk mencapai kesepadanan (equivalence) antara Bsu dan Bsa. Pergeseran itu dapat dibedakan menjadi empat macam:(1) structure shift, (2) class shift, (3) unit shift, dan (4) intra-system shift.

\section{a. Structure Shift}

Pergeseran struktur ini terjadi karena adanya perubahan susunan gramatika atau urutan kata dalam kalimat. Pergeseran ini bisa terjadi karena tuntutan tata bahasa sehingga bersifat wajib, namun dapat pula bersifat manasuka, yakni karena selera penerjemah atau karena mengikuti gaya penulisan (style) tertentu. Perhatikan contoh-contoh berikut ini:

Tsal: pabrik mainan

Tsu1: toy factory

Tsa2: stolen jewelry

Tsu2: perhiasan yang dicuri

Tsa3: Sebelummeninggalkan ruangan, dimatikannya lampu.

Tsu3: Before leaving the room, he turned the lamp off.

Tsa4: Ia mengambil bola itu dari dalam kotak.

Tsu4: The ball was taken out of the box.

Tsa5: Dengan tergesa-gesa dibukanya pintu itu.

Tsu5: He opened the door hurriedly.

Dapat kita lihat bahwa susunan katakata dalam masing-masing terjemahan berubah. Ada yang tidak mendapat perubahan lain selain pergeseran susunan kata (contoh pertama), namun ada pula yang masih mendapat tambahan kata (seperti contoh kedua), atau penghilangan sebagian elemen kalimat (contoh keempat), perubahan kata menjadi frasa (contoh keempat) dan perubahan frasa menjadi kata (contoh kelima). Pada prinsipnya, structure shift hanya menitikberatkan analisisnya pada pergeseran susunan kata dalam terjemahan. Perubahan kata 
menjadi frasa atau frasa menjadi kata berarti juga terjadi unit shift dalam terjemahan tersebut. Seperti terlihat pada contoh-contoh di atas, pergeseran itu dapat terjadi pada tataran frasa (contoh 1 dan 2), klausa (contoh 3), maupun kalimat (contoh 4 dan 5). Perubahan susunan dapat pula terjadi pada tataran kata, seperti pergeseran morfem "-able" dalam kata believable $\rightarrow$ dapat dipercaya, tetapi Catford tidak membahas ini dalam teorinya (1965:81).

\section{b. Class Shift}

Class shift terjadi jika terdapat pergeseran pada kelas kata (jenis kata) dalam penerjemahan. Kelas-kelas kata ini bisa jadi berbeda-beda antara satu bahasa dengan bahasa yang lain. Misalnya, dalam bahasa Inggris ada kelas kata $a d v e r b s$ yang biasanya dipadankan dengan frasa dalam bahasa Indonesia (misalnya "carefully" $\rightarrow$ "dengan hati hati") dan determiners yang sedikit berbeda penggunaannya dalam bahasa Indonesia meskipun bisa dicarikan padanannya (misalnya a/an $\rightarrow$ sebuah, sebutir, sehelai, dan sebagainya, dan this/these $\rightarrow$ ini).

Secara umum, dalam bahasa Inggris kita mengenal ada delapan kelas kata (parts of speech), empat kelas kata yang pertama disebut major classes atau content words, karena merupakan kata yang membawa informasi semantik dalam struktur kalimat, dan empat yang terakhir disebut minor classes atau structure words karena lebih berperan pada pembentukan struktur kalimat yang benar secara gramatika (DeCapua, 2008:27), yaitu: Noun (kata benda), Verb (kata kerja), Adjective (kata sifat), Adverb (kata keterangan), Preposition (kata depan), Pronoun (kata ganti), Conjunction (kata hubung), Determiner (kata penunjuk).

Class shift terjadi apabila terdapat pergeseran pada kelas kata tersebut, yang mungkin disebabkan oleh kelaziman ekspresi pada bahasa sasaran, atau karena adanya makna idiomatis dari bahasa sumber. Misalnya:

Tsu1: mechanical engineering (kata sifat)

Tsa1: teknik mesin (kata benda)

Tsu2: for the pursuit of happines (kata benda)

Tsa2: untuk mengejar kebahagiaan (kata kerja) Tsu3: for good (kata sifat)

Tsa3: untuk selamanya (kata keterangan)
Pada ungkapan-ungkapan yang bergaris bawah di atas terjadi pergeseran kelas kata, di mana ekspresi bahasa sumber diterjemahkan menjadi jenis kata yang berbada pada bahasa sasarannya.

\section{c. Unit Shift}

Machali (2000: 20-23), sebagaimana banyak ahli bahasa lainnya, menyatakan bahwa setiap bahasa mempunyai pola atau sistem tata bahasa yang mengandung hierarki lima satuan bahasa, yaitu: (1) morfem; (2) kata; (3) frasa; (4) klausa; dan (5) kalimat. Selanjutnya pada tataran yang lebih tinggi bisa kita kenali (6) paragraf dan (7) teks. Ketika penerjemahan yang dilakukan menjadikan adanya perubahan pada tataran satuan bahasa dari ungkapan Bsu ke Bsa, maka terjadilah unit shift atau rank shift. Bila pergeseran itu terjadi dari satuan yang lebih rendah ke satuan yang lebih tinggi ( 1 ke 2,1 ke 3, 2 ke 4, dan sebagainya) disebut upward rank shift. Sebaliknya, bila pergeseran itu terjadi dari satuan yang lebih tinggi ke satuan yang lebih rendah (3 ke 2, 4 ke 3, 3 ke 1, dan sebagainya) disebut downward rank shift.

Contoh:

\section{Tsu: gravity}

Tsa: gaya tarik bumi

Kata dalam Bsu diterjemahkan menjadi frasa dalam Bsa. Sebenarnya, kata "gravity" sudah ada padanannya dalam bahasa Indonesia, yaitu gravitasi. Berarti, di sini penerjemah melakukan translation shift berupa upward rank shift bukan karena keharusan tata bahasa, tetapi karena pilihan kata yang dikehendakinya sendiri.

Tsu: I don't know.

Tsa: Entahlah.

Dari sisi gramatika, kedua ekspresi itu sesunguhnya sama-sama berada pada tataran kalimat, yaitu Tsu merupakan kalimat lengkap (complete sentence), sedangkan Tsa merupakan kalimat minor (minor sentence). Tetapi kita bisa melihat secara struktur bahwa kalimat Tsu merupakan klausa, sedangkan kalimat Tsa merupakan kata, sehingga terdapat downward rank shift dalam penerjemahan yang dilakukan.

Tsu: Tiara sangat senang. Ia kembali menang dalam perlombaan itu. 
Tsa: Tiara is very happy because she won again in the competition.

Kedua kalimat dalam Tsu berubah menjadi klausa dalam Tsa, sehingga dalam hal ini juga terjadi downward rank shift dalam penerjemahan yang dilakukan.

\section{d. Intra-system Shift}

Catford (1965: 80) menggunakan istilah intra-system shifts ini untuk kasus-kasus dimana terjadi pergeseran karena disebabkan oleh tata bahasa yang berbeda dari kedua bahasa yang terlibat. Dalam hal ini, sebenarnya kedua Bsu dan Bsa memiliki sistem yang sepadan secara formal satu sama lain, namun penerjemahan yang dilakukan mengharuskan terjadinya pergeseran karena kelaziman ekspresi yang berkorespondensi itu menjadi tidak berterima. Ketidakberterimaan itu disebabkan oleh ketentuan tata bahasa dalam Bsa itu sendiri. Ada beberapa sebab yang dapat diidentifikasi sebagai penyebab intra-system shift ini, antara lain:

\section{1) Penggunaan noun sebagai referensi gene- rik}

Dalam bahasa Inggris, apabila kita hendak menunjuk kepada sesuatu benda secara umum, kita dapat menyatakan referensi generik itu dengan menggunakan kata benda tunggal, misalnya:

"A dog is an intelligent animal."

Dalam kalimat ini kita tidak merujuk kepada seekor anjing tertentu, hanya mengungkapkan konsep yang berlaku secara umum bahwa anjing adalah hewan yang cerdas. Pernyataan itu, dalam bahasa Indonesia sebenarnya dapat kita terjemahkan secara formal equivalent menjadi "Seekor anjing adalah seekor binatang yang cerdas." Tetapi ungkapan ini tidak berterima dalam bahasa Indonesia, sehingga dilakukan pergeseran menjadi "Anjing (adalah) binatang yang cerdas." (Kata "adalah" dalam kalimat itu bersifat manasuka).

Dari contoh tersebut, determiner atau article "a" dan "an" tidak direalisasikan dalam terjemahan. Fenomena ini biasa disebut sebagai zero translation atau omission. Dalam Bahasa Indonesia, tidak perlu mengeksplisitkan kata bilangan "a" atau "an" menjadi "satu, sebuah, seekor, sebilah", dan sebagainya, bila merujuk kepada kata benda generik, meskipun secara formal pasangan kata tersebut berkorespondensi formal.

Pada kenyataannya, dalam bahasa Inggris, eskpresi “a dog" dan "an... animal” tersebut di atas dapat pula direalisasikan dalam bentuk plural, tanpa mengubah makna dan fungsi kalimatnya yang merujuk kepada kata benda generik. Namun, harus dilakukan penyesuaian terhadap kata lainnya agar kalimat tersebut berterima. Sehingga, kalimat itu menjadi "Dogs are intelligent animals", dan terjemahannya tetap sama dalam bahasa Indonesia, yaitu " $A n$ jing (adalah) binatang yang cerdas", dan tidak dapat diekpresikan rujukannya dalam bentuk jamak menjadi "Anjing-anjing adalah binatangbinatang yang cerdas”.

\section{2) Penggunaan kata benda jamak setelah kata penunjuk jamak.}

Bentuk tunggal dan jamak ada dalam bahasa Indonesia dan bahasa Inggris, sehingga saling berkorespondensi. Misalnya:

Tsu: Houses in downtown area are very expensive.

Tsa: Rumah-rumah di pusat kota sangat mahal.

Kita ketahui bahwa dalam contoh ini, kata "houses" memiliki korespondensi formal dengan kata "rumah-rumah". Akan tetapi, ketika bentuk jamak itu didahului oleh kata penunjuk jumlah jamak, yang mengindikasikan bahwa kata benda di belakangnya berjumlah lebih dari satu, maka terdapat perbedaan dalam sistem tata bahasa kedua bahasa tersebut.

Jika referensinya mengacu pada kata benda yang dapat dihitung (countable nouns) dalam bahasa Inggris, setiap kali ada kata penunjuk (determiner) yang mengindikasikan jumlahnya lebih dari satu, maka bentuk kata benda tersebut harus - tidak boleh tidak -berbentuk plural. Perbedaan sistem tata bahasa ini menyebabkan terjadinya intra-system shiftsdalam penerjemahan.

Example:

SL: Many houses on the coast were swept away by the flood.

TL: Banyak rumah di pinggir pantai tersapu banjir.

Kata "houses" memang harus dalam bentuk jamak (plural) dalam sistem tata bahasa 
Inggris, karena adanya kata penunjuk jamak di depannya, yaitu "many", agar memenuhi kaidah kebahasaan(agreement / concordance). Sebaliknya, dalam bahasa Bahasa Indonesia, bila sudah terdapat pemarkah yang menunjukkan jamak dalam frasa kata benda, maka kata benda yang mengikutinya tidak boleh berbentuk jamak (dalam hal ini, berupa kata ulang). Sehingga, ekspresi "banyak rumah-rumah" justru menjadi rancu atau tidak tepat.

Dengan demikian, ketika sebaliknya menerjemahkan dari bahasa Indonesia ke bahasa Inggris, hal ini juga perlu diperhatikan.

Contoh:

Bsu: Ada lima siswa dan dua guru yang datang terlambat kemarin.

Bsa: There were five students and two teachers who came late yesterday.

Jadi, pergeseran (shift) yang terjadai dalam kasus ini merupakan intra system shift, yang diwajibkan oleh sistem tata bahasa dari bahasa sasarannya.

\section{3) Perbedaan konsep pluralitas pada kata tertentu}

Intra-system shift juga dapat terjadi ketika kita menerjemahkan kata-kata yang dipandang secara berbeda oleh kedua komunitas pengguna bahasa ini. Perbedaan ini karena satu pihak memahami benda itu sebagai satu kesatuan, sementara pihak lain memahaminya sebagai dua bagian yang menjadi satu. Perhatikan contoh berikut:

\begin{tabular}{cc}
\hline Bahasa Inggris & Bahasa Indonesia \\
\hline a pair of trousers & sebuah celana \\
a pair of scissors & sebuah gunting \\
a pair of glasses & sebuah kacamata
\end{tabular}

Ketiga kata benda itu (celana, gunting, dan kacamata) merupakan benda yang tunggal dalam bahasa Indonesia, sementara dalam bahasa Inggris dinilai sebagai dua bagian yang harus menjadi satu agar dapat berfungsi sesuai dengan tujuannya. Sehingga bila dalam bahasa Indonesia digunakan kata bilangan jamak atau menggunakan kata ulang penerjemahannya ke bahasa Inggris perlu dilakukan dengan seksama:

\begin{tabular}{cc}
\hline Bahasa Indonesia & Bahasa Inggris \\
\hline dua celana & two pairs of trousers \\
sepuluh celana pendek & ten pairs of shorts \\
sepasang kacamata & two pairs of glasses \\
banyak gunting & many scissors \\
celana-celana itu & those trousers \\
\hline
\end{tabular}

Namun konsep ini akan berbeda bila benda yang dimaksud merupakan sepasang benda yang secara empiris terlihat lepas dan tidak menyatu satu sama lain, meskipun normalnya dipakai secara bersama-sama sebagai satu kesatuan utuh, sehingga baik dalam bahasa Indonesia maupun bahasa Inggris, benda-benda tersebut dianggap sebagai dua bagian yang terpisah seperti tampak pada tabel berikut ini.

\begin{tabular}{cc}
\hline Bahasa Inggris & Bahasa Indonesia \\
\hline a pair of sandals & sepasang sandal \\
a pair of shoes & sepasang sepatu \\
a pair of gloves & sepasang sarung-tangan \\
ten pairs of shoes & sepuluh pasang sepatu \\
\hline
\end{tabular}

Pada ketiga contoh di atas tidak terdapat perbedaan konsep, sehingga tidak terjadi pergeseran dalam penerjemahaannya (zero shift).

\section{4) Perbedaan konsep kala dan tenses}

Intra-system shift dapat pula terjadi ketika misalnya, dalam bahasa Indonesia kita dapat menyatakan ekspresi "Saya sudah bertemu Budi minggu lalu". Dalam hal ini, kita harus memilih apakah mengekspresikan kala perfektif dengan bentuk "have+Vb3" atau menekankan pada waktu kejadiannya dalam kala lampau (Vb2). Sehingga, terjemahannya dapat menjadi: "I have met Budi" atau "I met Budi last week".Dalam hal ini, kita tidak dapat mengungkapkan kedua penanda perfektif dan lampau dalam bahasa Inggris menjadi "I have met Budi last week", karena sistem tata bahasanya akan menyatakan kalimat itu sebagai tidak berterima atau tidak natural.

Sementara itu, Machali (2000:63) menggunakan istilah "pergeseran bentuk" atau "transposisi" dengan pengertian yang sekilas tampaknya berbeda dari teori translation shiftyang diperkenalkan oleh Catford.Namun bila dicer- 
mati lebih dalam, pada hakikatnya apa yang diuraikan oleh Machali sudah tercakup dalam dua jenis translation shift yang diajukan Catford di atas, hanya perbedaannya lebih pada penekanannya dalam alasan terjadinya shift tersebut. Machali (2000:63-71; cf. Newmark, 1988:8588) menyatakan ada empat jenis pergeseran bentuk, yaitu:

(1) Pergeseran bentuk wajib dan otomatis yang disebabkan oleh sistem dan kaidah bahasa. Dalam hal ini, penerjemah tidak mempunyai pilihan lain selain melakukannya. Dalam konsep ini Machali memberikan contoh yang merupakan gabungan antara intrasystem shift (a pair of trousers $\rightarrow$ sebuah celana) dan structure shift (beautiful woman $\rightarrow$ wanita cantik; football field $\rightarrow$ lapangan sepakbola).

(2) Pergeseran yang dilakukan apabila suatu struktur gramatikal dalam Bsu tidak ada dalam Bsa. Dalam pergeseran jenis kedua ini, juga diberikan contoh yang merupakan structure shift (Buku itu harus kita bawa $\rightarrow$ We must bring the book; telah disahkan penggunaannya $\rightarrow$ its usage has been approved).

(3) Pergeseran yang dilakukan karena alasan kewajaran ungkapan; kadang-kadang, sekalipun dimugkinkan adanya terjemahan harfiah menurut struktur gramatikal, padanannya menjadi tidak wajar atau kaku dalam Bsa. Dalam pergeseran jenis ketiga ini, Machali diberikan contoh yang berupa classshift (medical student $\rightarrow$ mahasiswa kedokteran; I disavow any knowledge of... $\rightarrow$ saya menyangkal mengetahui...) dan unit shift (The approval signed by the docter $i$ s valid $\rightarrow$ Persetujuan yang ditandatangani oleh dokter itu valid; lending bank $\rightarrow$ bank yang memberikan pinjaman)

(4) Pergeseran yang dilakukan untuk mengisi kerumpangan kosakata (termasuk perangkat tekstual seperti /-pun/ dalam bahasa Indonesia) dengan menggunakan suatu struktur gramatikal. Di sini contoh-contoh yang diberikan termasuk dalam level shift (Perjanjian inilah yang diacu $\rightarrow$ It is this agreement which is referred to) dan unit shift (adept $\rightarrow$ sangat terampil; interchange- ability $\rightarrow$ keadaan dapat saling dipertukarkan).

\section{SIMPULAN}

Kegiatan penerjemahan yang semakin berkembang dengan berbagai sudut pandang keilmuan sangat menarik untuk diteliti. Penggunaan translation shift dalam analisis penerjemahan masih sering dilakukan dan relevan digunakan karena konsep ini masih tetap sesuai dengan teori dan praktik penerjemahan kontemporer. Model analisis translation shift yang dibahas dalam bisa digunakan sebagai model yang untuk analisis produk terjemahan dalam penelitian-penelitian. Diperlukan kejelian dan kecermatan dalam menerapkan konsep translation shift ini karena beberapa konsep dapat saling berkaitan sehingga tidak terjadi kekeliruan dalam analisisnya.

\section{DAFTAR PUSTAKA}

Al-Zoubi, Mohammad Q.R. 2003. "Constructing a Model for Shift Analysis in Translation". http://www.translationdirectory. com/article11.htm, diakses tanggal 30 Maret 2014.

Baker, Mona. (1992). In Other Words, A Coursebook on Translation. London : Routledge, 11 New FetterLane, EC4P 4EE

Bell, T. Roger. 1991. Translation and Translating: Theory and Practice. NewYork: Longman Inc

Catford, J. C. 1965. A Linguistic Theory of Translation. London: Oxford University Press.

DeCapua, Andrea. 2008. Grammar for Teachers: A Guide to American English for Native and Non-Native Speakers. New York: Springer.

Halliday, M.A.K. and Matthiessen, C.M.I.M. 2004. An Introduction to Functional Grammar. Third Edition. London: Arnold.

Hariyanto, Sugeng. 2013. Seri Teori (3:) Ian Catford-Pergeseran Terjemahan. http:// resources.transbahasa.com/2013/09/30/ seri-teori-3-ian-catford, diakses pada tanggal 3 April 2014. 
Larson, Mildred L. 1984. Meaning-Based Translation: A Guide to Cross-Language Equivalence. Boston: University Press of America.

Listiari, Kartika P. 2013. An Analysis of Category Shifts in the Movie Subtitle of Clint Eastwood's Million Dollar Baby and Its Bahasa Indonesia Translation. Skripsi. Yogyakarta: Univ. Negeri Yogyakarta.

Newmark, Peter. 1988. A Textbook on Translation. UK: Prentice Hall.
Nugroho, Kartika P. 2013. Category Shifts in Dave Pelzers' A Child Called It and Its Bahasa Indonesia Translation. Skripsi. Yogyakarta: Univ. Negeri Yogyakarta.

Pradipta, Anisa Maya. 2013. The Effects of Rank Shift in Isabella Swan's Characterization as the Main Character in Twilight Movie Texts.

Winarna. 2009. An Analysis on the Translation of Non-Minimal English Noun Phrases in John Grisham's The Testamentas Seen in Hendarto Setiati's Surat Wasiat. Tesis. Yogyakarta: Univ. Sanata Dharma. 